\title{
IMPLEMENTASI TRANSFORMASI FOURIER UNTUK TRANSFORMASI DOMAIN WAKTU KE DOMAIN FREKUENSI PADA LUARAN PURWARUPA ALAT PENDETEKSIAN GULA DARAH SECARA NON-INVASIF
}

\author{
Umam Hidayaturrohman ${ }^{1}$, Erfiani ${ }^{2 \ddagger}$, and Farit M Afendi ${ }^{3}$ \\ 1Department of Statistics, IPB University, Indonesia, hidayaturrohman4@ymail.com \\ 2 Department of Statistics, IPB University, Indonesia, erfiani@apps.ipb.ac.id \\ ${ }^{3}$ Department of Statistics, IPB University, Indonesia, fmafendi@gmail.com \\ ${ }_{\text {Fcorresponding author }}$
}

Indonesian Journal of Statistics and Its Applications (eISSN:2599-0802)

Vol 4 No 2 (2020), 234 - 244

Copyright (C 2020 Umam Hidayaturrohman, Erfiani, and Farit M Afendi. This is an open-access article distributed under the Creative Commons Attribution License, which permits unrestricted use, distribution, and reproduction in any medium, provided the original work is properly cited.

\begin{abstract}
Diabetes mellitus is the result of changes in the body caused by a decrease of insulin performance which is characterized by an increase of blood sugar level. Detection of blood sugar can be done with Invasive methods or non-invasive methods. However, non-invasive methods are considered better because they can check early, faster and accurate. The prototype output is values of intensity in the time domain, thus fourier transformation is very much needed to transform into the frequency domain. In this study, Fourier transformation methods used are Discrete Fourier Transform (DFT), Fast Fourier Transform Radix-2, and Fast Fourier Transform Radix-4. Evaluation for the best method is done by comparing the processing speed of each method. The FFT Radix-4 method is more effective to perform the transformation into the frequency domain. The average processing speed with the FFT Radix-4 method reaches $2.67 \times 10^{5}$ nanoseconds, and this is much faster $5.06 \times 10^{6}$ nanoseconds than the FFT Radix-2 method and $2.40 \times 10^{7}$ nanoseconds faster than the DFT method.
\end{abstract}

Keywords: DFT, Diabetes Mellitus, FFT Radix-2, FFT Radix-4, Non-Invasive.

\section{Pendahuluan}

Diabetes melitus ditandai dengan peningkatan gula darah yang tinggi yang berakibat pada munculnya berbagai komplikasi penyakit jangka Panjang didalam tubuh ( $\mathrm{Li}$,

\footnotetext{
* Received Jul 2019; Accepted Jul 2020; Published online on Jul 2020
} 
1997). Peningkatan kadar gula darah dalam tubuh disebabkan oleh hilangnya kemampuan sel yang memproduksi insulin di pankreas atau penurunan sensitivitas jaringan tubuh terhadap insulin (Kassahun \& Mekonen, 2017). Oleh sebab itu, pencegahan diabetes melitus sangat diperlukan terutama dalam hal perbaikan terhadap pola perilaku yang berkaitan dengan makanan dan aktifitas fisik (Fain, 2009).

Selain itu, pemeriksaan kadar gula darah dianggap penting bagi seorang penderita diabetes, baik dilakukan secara melukai (invasif) maupun tanpa melukai (non-invasif). Dewasa ini penggunaan metode secara invasif dianggap kurang efektif bagi penderita. Pemeriksaan rutin secara invasif dapat menyebabkan infeksi sebagai akibat dari berkurangnya kemampuan tubuh penderita dalam memproduksi insulin.

Sebagai alternatif, pengukuran gula darah secara non-invasif mulai dikembangkan untuk meningkatkan frekuensi pemantauan gula darah secara mandiri. Penggunaan metode non-invasif dapat dilakukan dengan menggunakan media cairan tubuh ataupun menggunakan media spektroskopi. Dewasa ini, pengukuran kadar gula darah secara non-invasif berbasis spektroskopi mulai dikembangkan seperti Tedjo et al. (2014) menggunakan metode spektroskopi untuk melakukan pendeteksian gula darah, namun hasil penelitian yang diproleh memiliki nilai standar error prediksi yang masih tinggi.

Gabungan peneliti dari Departemen Gizi dan Masyarakat IPB, Departemen Fisika, Departemen Biologi, Departemen Statistika dan Departemen IImu Komunikasi di lingkungan Institut pertanian Bogor menciptakan purwarupa alat pendeteksian gula darah secara non-invasif. Purwarupa alat ditujukan untuk melakukan pemeriksaan yang lebih awal, cepat dan akurat. Luaran purwarupa alat non-invasif memiliki luaran berupa nilai intensitas dalam domain waktu yang digambarkan dengan pola spektrum. Analisis sinyal dalam domain waktu memerlukan analisis yang cukup panjang karena melibatkan turunan dan fungsi dari sinyal yang berakibat ketidak-detailan hasil analisis. Analisis sinyal dalam domain frekuensi akan lebih mudah untuk dilakukan. Oleh karena itu, diperlukan cara untuk melakukan transformasi ke domain frekuensi untuk menunjang analisis lebih lanjut.

Transformasi Fourier merupakan salah satu metode popular yang sering digunakan untuk mengubah bentuk waktu bentuk frekuensi yang ditujukan untuk mempermudah analisis. Penelitian sebelumnya yang menggunakan Transformasi Fourier sebagai dasar analisis seperti (Almeida-Trinidad \& Garnica-Garza, 2007) menggunakan Fourier untuk menguraikan spektrum luaran IMRT (Intensity Modulated Radiation Therapy). Wintarti \& Suprapto (2011) membandingkan penggunaan Discrete fourier Transform (DFT) dan Fast Fourier Transform (FFT). Hasil yang diproleh yaitu penggunaan metode FFT lebih efektif jika dibandingkan dengan DFT. Jaladi \& Swamy (2015) mensimulasikan penggunaan FFT Radix-2, FFT Radix-4 dan FFT Radix-8 untuk dibandingkan keefektifan algoritmanya. Diperoleh hasil yaitu FFT dengan Radix yang lebih tinggi akan lebih efektif dengan Radix yang lebih rendah.

Berdasarkan uraian diatas akan diimplementasikan algoritma DFT, FFT Radix-2 dan FFT Radix-4 untuk melakukan transformasi data dari domain waktu ke domain frekuensi sebagai bagian dari pra-pemerosesan data luaran purwarupa alat pendeteksian gula darah secara non-invasif. 


\section{Discrete Fourier Transform (DFT)}

Transformasi Fourier pertama kali diperkenalkan oleh matematikawan dan fisikawan asal Prancis yaitu Josep Fourier (1768-1830). Metode ini dianggap yang terbaik dalam hal analisis spekrum (Kim, 2003). Secara garis besar, metode Transformasi Fourier dibagi menjadi 2 bagian yaitu Fourier Kontinu dan Fourier Diskret. Transformasi Fourier Kontinu banyak dilakukan pada sistem yang sederhana dan data yang sedikit karena memberikan hasil yang sangat baik. Jika sudah kompleks dan data yang dilibatkan banyak, penerapannya akan sulit dilakukan bahkan tidak dapat untuk diselesaikan (Lasijo, 2005). Untuk mengatasi berbagai permasalahan pada penggunaan Transformasi Fourier Kontinu maka mulai dikembangkan Transformasi Fourier Diskret.

Bentuk umum dari Transformasi Fourier Diskret dinyatakan dengan persamaan berikut.

$$
\begin{aligned}
& X(m)=\sum_{n=0}^{N-1} x(n) W_{N}^{m n} \\
& x(n)=\frac{1}{N} \sum_{k=0}^{N-1} X(m) W_{N}^{-m n} \\
& \text { nilai } W_{N}=e^{-j\left(\frac{2 \pi}{N}\right)} \text { dan } N=\text { Length }[x(n)]
\end{aligned}
$$

Keterangan:

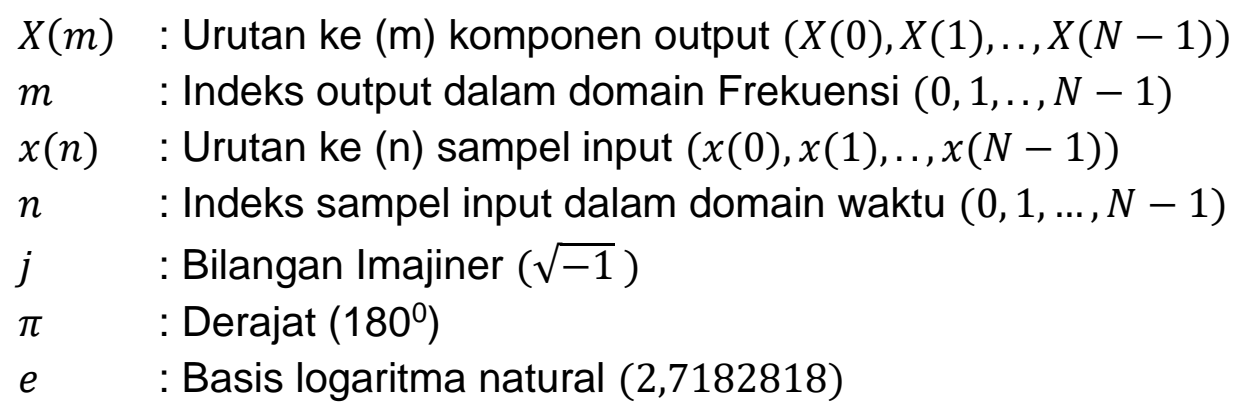

\section{Fast Fourier Transform (FFT)}

Metode Fast Fourier Transform (FFT) pertama kali diperkenalkan oleh Cooley dan Tukey sebagai pengembangan dari Discrete Fourier Transform (DFT) untuk mengatasi masalah yang ada pada Fourier Kontinu. Menurut Zhang \& Li (2013) metode FFT memiliki tingkat keefisienan yang tinggi dalam melakukan Transformasi Fourier Diskret. Adapun algoritma pemerosesan FFT yaitu: (1) $\mathrm{N}$-titik domain waktu disegmentasi sebagai input. (2) Menghitung setiap poin sinyal untuk memproleh domain frekuensi. (3) $\mathrm{N}$ domain frekuensi digabungkan dalam urutan tertentu untuk mendapatkan spektrum yang dibutuhkan. Teknik dasar FFT pada prinsipnya yaitu dengan memotong input (domain waktu) DFT menjadi beberapa bagian (2, 4, 8, dan seterusnya). Hal inilah yang disebut sebagai istilah Radix dalam metode FFT. 


\subsection{Fast Fourier Transform Radix-2.}

Persamaan FFT didapatkan dengan menguraikan bentuk DFT. Data input dalam domain waktu disegmentasikan menjadi 2 bagian dalam bentuk ganjil dan genap, sehingga bentuk umum dari FFT Radix-2 dapat dituliskan dengan persamaan berikut.

$$
X(m)=\sum_{n=0}^{\frac{N}{2}-1} x(2 n) e^{-j 2 \pi(2 n) m / N}+\sum_{n=0}^{\frac{N}{2}-1} x(2 n+1) e^{-j 2 \pi(2 n+1) m / N}
$$

Berdasarkan Persamaan 2, diketahui nilai $W_{N}=e^{-j\left(\frac{2 \pi}{N}\right)}$ maka persamaan 3 dapat diuraikan lebih lanjut sehingga dapat diproleh bentuk persamaan (4).

$$
X(m)=\sum_{n=0}^{\frac{N}{2}-1} x(2 n) W_{\frac{N}{2}}^{n m}+\sum_{n=0}^{\frac{N}{2}-1} x(2 n+1) W_{\frac{N}{2}}^{n m} W_{N}^{m}
$$

Bentuk Persamaan 4 masih dalam bentuk segmentasi dalam domain waktu. Selain menguraikan domain waktu, dilakukan hal yang sama untuk domain frekuensi.

$$
\begin{aligned}
X(m+N / 2) & =\sum_{n=0}^{\frac{N}{2}-1} x(2 n) W_{\frac{N}{2}}^{n\left(m+\frac{N}{2}\right)}+\sum_{n=0}^{\frac{N}{2}-1} x(2 n+1) W_{\frac{N}{2}}^{n\left(m+\frac{N}{2}\right)} W_{N}^{\left(m+\frac{N}{2}\right)} \\
& =\sum_{n=0}^{\frac{N}{2}-1} x(2 n) W_{\frac{N}{2}}^{n m}-\sum_{n=0}^{\frac{N}{2}-1} x(2 n+1) W_{\frac{N}{2}}^{n m} W_{N}^{m}
\end{aligned}
$$

Bentuk Fast Fourier Transform Radix-2 dapat digambarkan dan diselesaikan dengan menggunakan diagram kupu-kupu (Zhang \& Li, 2013). Gambar 1 adalah ilustrasi bentuk diagram kupu-kupu untuk FFT Radix-2.

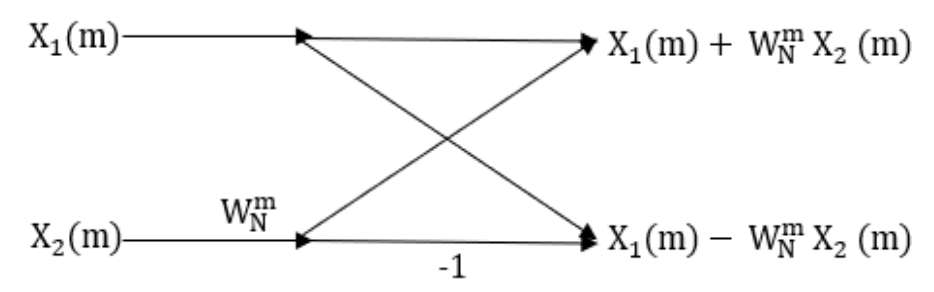

Gambar 1: Diagram kupu-kupu FFT Radix-2.

\subsection{Fast Fourier Transform Radix-4}

Fast Fourier Transform Radix-4 pada prinsifnya memiliki konsep yang sama dengan FFT Radix-2, yaitu dengan membagi sinyal input (domain waktu) menjadi 4 bagian. Sehingga bentuk umum dari formula FFT Radix-4 yaitu: 


$$
\begin{aligned}
X(m)= & \sum_{n=0}^{\frac{N}{4}-1} x(4 n) W_{N}^{(4 n) m}+\sum_{n=0}^{\frac{N}{4}-1} x(4 n+1) W_{N}^{(4 n+1) m} \\
& +\sum_{n=0}^{\frac{N}{4}-1} x(4 n+2) W_{N}^{(4 n+2) m}
\end{aligned}
$$

Sebagaimana FFT Radix-2, formula FFT Radix-4 dapat diaplikasikan ke diagram kupu-kupu (butterfly diagram) untuk mempermudah proses transformasi data. Gambar 2 merupakan bentuk umum dari diagram kupu-kupu untuk FFT Radix-4 (Zhang \& Li, 2013).

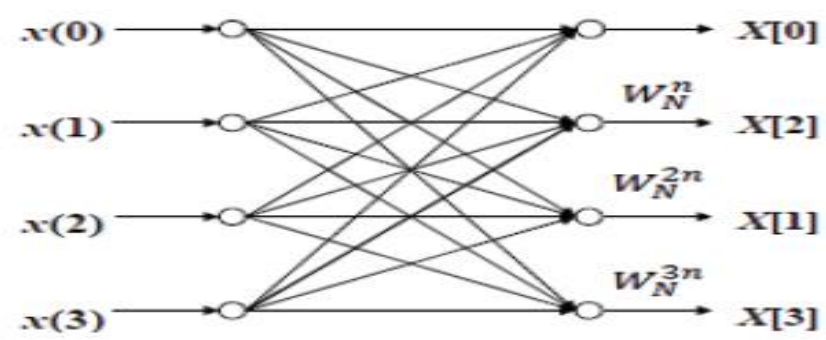

Gambar 2: Diagram kupu-kupu FFT Radix-4.

\section{Metodologi Penelitian}

\subsection{Data}

Data dalam penelitian ini penggunakan data primer yang didapatkan dari hasil pengukuran kadar gula darah sewaktu dari 120 responden. Proses pengukuran dilakukan dengan menggunakan alat pemantauan kadar gula darah secara noninvasif. pengukuran dilakukan dengan cara melakukan penyensoran pada jari manis responden dengan pengulangan sebanyak 5 kali ulangan pada setiap responden. Oleh karena itu, total spektrum yang ditransformasi menjadi 600 spektrum.

Data merupakan bagian dari penelitian "Pengembangan dan Uji Klinis Purwarupa Alat Pemantauan Kadar Glukosa Darah Non-Invasif Institut Pertanian Bogor" yang dilaksanakan pada April 2016 - Januari 2017. Pelaksanaan pengambilan data bertempat di Laboratorium Biokimia, Departemen Gizi dan Masyarakat IPB. Penelitian didanai oleh program Riset dan Sistem Inovasi Nasional, Kementrian Riset dan Teknologi dan Pendidikan Tinggi.

\subsection{Prosedur Analisis Data}

Penelitian ini menggunakan Transformasi Fourier yang ditujukan untuk melakukan transformasi data dari domain waktu ke domain frekuensi. Metode Transformasi Fourier yang digunakan yaitu metode Discrete Fourier Transform (DFT) dan metode Fast Fourier Transform (FFT) Radix-2 dan Fast Fourier Transform Radix 4. Evaluasi metode terbaik diproleh dengan membandingkan kecepatan pemerosesan metode. 
keseluruhan proses analisis data dalam penelitian ini menggunakan bantuan Microsoft Excel, $R$ dan Matlab. Berikut adalah tahapan-tahapan dalam proses analisis data.

\section{a. Discrete Fourier Transform (DFT)}

(1) Ambil N-titik domain waktu untuk ditransformasikan ke domain frekuensi.

(2) Mengaplikasikan formula DFT pada persamaan 3 untuk melakukan transformasi.

(3) Hasil transformasi dalam bentuk bilangan kompleks sehingga nilai mutlak frekuensi perlu untuk diketahui dengan formula.

$$
\sqrt{[\operatorname{Riil}(z)]^{2}+[\operatorname{Imajiner}(z)]^{2}}
$$

(4) Gambar plot dari nilai mutlak frekuensi.

(5) Evaluasi kecepatan algoritma pemrograman diproleh dengan menggunakan bantuan software Matlab.

\section{b. Fast Fourier Transform (FFT)}

(1) N-titik domain waktu dibagi ke $\mathrm{N}$ sinyal dengan domain waktu dari satu titik (segmentasi Sinyal) dengan cara menentukan jumlah Radix yang akan digunakan untuk transformasi dengan metode FFT.

(2) Melakukan transformasi sinyal ke domain frekuensi dengan menggunakan formula FFT untuk masing-masing Radix.

(3) Mengaplikasikan formula FFT dalam bentuk diagram kupu-kupu (butterfly diagram) untuk mempermudah proses perhitungan.

(4) Hitung nilai mutlak frekuensi

(5) Evaluasi kecepatan algoritma pemrograman FFT Radix-2 dan FFT Radix-4 diproleh dengan menggunakan bantuan software Matlab.

\section{Hasil dan Pembahasan}

Luaran purwarupa alat pendeteksian gula darah secara non-invasif berupa nilai intensitas dalam domain waktu. Bentuk luaran purwarupa alat non-invasif pada dasarnya memiliki pola yang hampir sama pada setiap responden. bentuk umum plot luaran alat non-invasif terlihat pada Gambar 3.

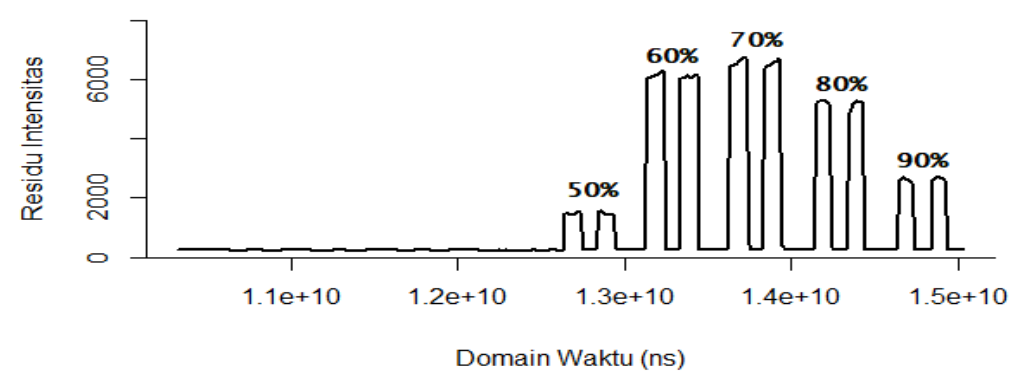

Gambar 3: Plot intenstas residual luaran purwarupa alat non-invasif.

Pola luaran purwarupa non-invasif terdiri dari 5 modulasi yaitu modulasi $50 \%, 60 \%$, $70 \%$, 80\% dan 90\%. Pada setiap modulasi terdapat 2 puncak. Hal ini dikarenakan pada setiap modulasi terdapat kondisi yaitu lampu inframerah dinyalakan 2 kali dan 1 
kali lampu inframerah dimatikan. Nilai residu intensitas akan meningkat ketika lampu inframerah dalam kondisi hidup. Sebaliknya, nilai residu intensitas lebih kecil ketika lampu dalam kondisi mati.

Berdasarkan Gambar 3 terlihat pola grafik memiliki nilai residu intensitas yang cukup rendah pada detik-detik awal yaitu mulai dari detik ke \pm 10 hingga detik ke \pm 12.5 . Residu intensitas terjadi peningkatan seiring dengan adanya pergantian modulasi. modulasi $50 \%$ selalu memiliki nilai residu intensitas terendah jika dibandingkan dengan modulasi lainnya. Residu intensitas tertinggi selalu berada pada modulasi $70 \%$.

\subsection{Hasil Transformasi Fourier}

Transformasi domain waktu ke frekuensi dalam penelitian ini menggunakan algoritma Fourier dengan metode Discrete Fourier Transform, Fast Fourier Transform Radix-2, dan Fast Fourier Transform Radix-4. Digunakan 256 titik (n) sinyal dalam domain waktu untuk dilakukan transformasi ke domain frekuensi. Tabel 1 merupakan contoh hasil Transformasi Fourier untuk Responden 109 (kadar gula darah 68 mg/dl), Responden 03 (kadar gula darah 80 mg/dl), Responden 71 (kadar gula darah 105 $\mathrm{mg} / \mathrm{dl}$ ), dan Responden 73 (kadar gula darah 276 mg/dl).

Tabel 1: Hasil Transformasi Fourier untuk Responden 109, Responden 03, Responden 71, dan Responden 73.

\begin{tabular}{rrrrr}
\hline$m$ & Responden 109 & \multicolumn{1}{c}{ Responden 03 } & \multicolumn{1}{c}{ Responden 71 } & \multicolumn{1}{c}{ Responden 73 } \\
\hline 1 & $196158.000+0.000 \mathrm{i}$ & $295155.000+0.000 \mathrm{i}$ & $215224.000+0.000 \mathrm{i}$ & $225642.000+0.000 \mathrm{i}$ \\
2 & $-2511.876+98348.796 \mathrm{i}$ & $-25425.356+177518.046 \mathrm{i}$ & $-8574.340+111236.788 \mathrm{i}$ & $-4702.966+123394.604 \mathrm{i}$ \\
3 & $-37421.970-7487.928 \mathrm{i}$ & $-61181.698-31756.877 \mathrm{i}$ & $-40672.274-12177.838 \mathrm{i}$ & $-54338.484-8260.687 \mathrm{i}$ \\
4 & $10918.115-501.777 \mathrm{i}$ & $23039.038+8922.204 \mathrm{i}$ & $10625.746+4271.371 \mathrm{i}$ & $9419.688-7985.843 \mathrm{i}$ \\
& $\ldots$ & $\ldots$ & $\ldots$ & $\ldots$ \\
254 & $10918.115+501.777 \mathrm{i}$ & $23039.038-8922.204 \mathrm{i}$ & $10625.746-4271.371 \mathrm{i}$ & $9419.688+7985.843 \mathrm{i}$ \\
255 & $-37421.970+7487.928 \mathrm{i}$ & $-61181.698+31756.877 \mathrm{i}$ & $-40672.274+12177.838 \mathrm{i}$ & $-54338.484+8260.687 \mathrm{i}$ \\
256 & $-2511.876-98348.796 \mathrm{i}$ & $-25425.356-177518.046 \mathrm{i}$ & $-8574.340-111236.788 \mathrm{i}$ & $-4702.966-123394.604 \mathrm{i}$ \\
\hline
\end{tabular}

Keterangan: " $m$ " merupakan indeks output dalam domain frekuensi

Hasil Transformasi Fourier dalam bentuk bilangan kompleks yang terdiri dari unsur bilangan Real dan bilangan Imajiner. Untuk mempermudah analisis dan interpretasi hasil transformasi diubah ke bentuk bilangan mutlak. Bentuk matematis untuk mengubah bentuk bilangan komleks ke bentuk bilangan mutlak yaitu $|z|=|x+y i|=$ $\sqrt{x^{2}+y^{2}}=\sqrt{[\operatorname{Re}(z)]^{2}+[\operatorname{Im}(z)]^{2}}$. Re merupakan unsur bilangan Real dan Im merupakan unsur bilangan Imajiner. Tabel 2 merupakan bentuk mutlak hasil transformasi dari Responden 109, Responden 03, Responden 71, dan Responden 73 dalam domain frekuensi.

Berdasarkan hasil Transformasi Fourier pada Tabel 2, terlihat hasil transformasi seperti ada perulangan pada setiap responden. Hasil transformasi pada $\mathrm{m}-2$ memiliki nilai yang sama dengan $m-256$, nilai $m-3=m-255$, nilai $m-4=m-254$ dan seterusnya. Gambar 4 merupakan bentuk pola grafik dalam domain frekuensi dari Tabel 2 untuk masing-masing responden. 
Tabel 2: Nilai mutlak hasil Transformasi Fourier untuk Responden 109, Responden 03, Responden 71, dan Responden 73.

\begin{tabular}{|c|c|c|c|c|}
\hline$m$ & Responden 109 & Responden 03 & Responden 71 & Responden 73 \\
\hline 1 & 196158.00 & 295155.00 & 215224.00 & 225642.00 \\
\hline 2 & 98380.87 & 179329.60 & 111566.76 & 123484.19 \\
\hline 3 & 38163.76 & 68932.57 & 42456.26 & 54962.8 \\
\hline 4 & 10929.64 & 24706.34 & 11452.12 & 12349.26 \\
\hline$\ldots$ & & & & \\
\hline 254 & 10929.64 & 24706.34 & 11452.12 & 12349.26 \\
\hline 255 & 38163.76 & 68932.57 & 42456.26 & 54962.8 \\
\hline 256 & 98380.87 & 179329.60 & 111566.76 & 123484.19 \\
\hline
\end{tabular}

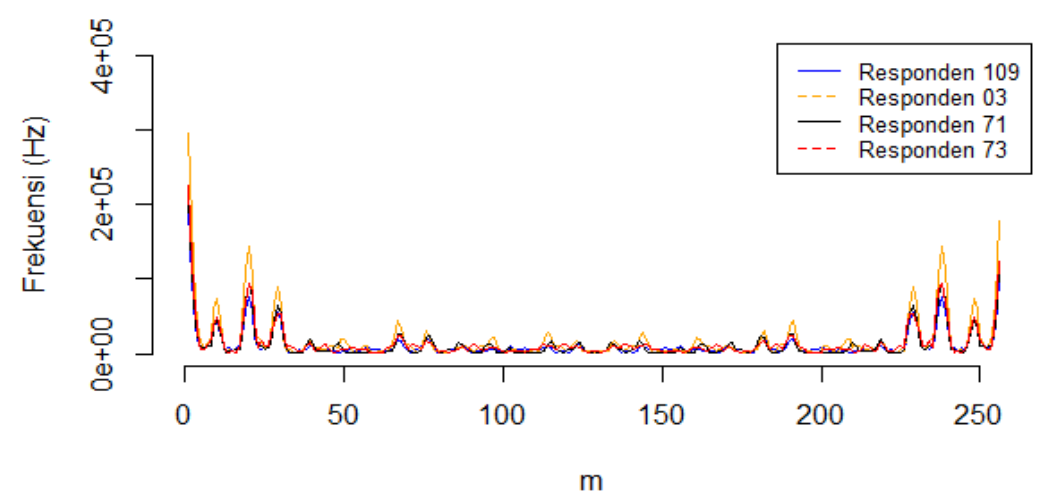

Gambar 4: Perbandingan hasil transformasi fourier pada Responden 109, Responden 03, Responden 71, dan Responden 73.

Secara umum pola grafik hasil Transformasi Fourier pada setiap responden memiliki bentuk pola grafik yang hampir sama. Berdasarkan grafik pada Gambar 4 terlihat mayoritas Responden 03 (kadar gula darah $80 \mathrm{mg} / \mathrm{dl}$ ) memiliki nilai frekuensi yang lebih tinggi dari pada plot grafik untuk responden lainnya. Oleh sebab itu, dapat ditarik kesimpulan berdasarkan grafik bahwa pola kadar gula darah tidak linear. Responden dengan kadar gula darah yang tinggi (Responden 73) belum tentu memiliki pola frekuensi kadar gula darah yang lebih tinggi dibandingkan dengan responden yang lain, begitu pula sebaliknya. Berdasarkan grafik terlihat jelas bahwa pola data hasil transformasi membentuk pola pengulangan dan terdapat unsur periodik. Hal ini sebagai akibat dari unsur $2 \pi$ dalam persamaan Fourier. Oleh sebab itu, perhitungan Transformasi Fourier dapat dilakukan pada setengah periode data.

Algoritma DFT, FFT Radix-2 dan FFT-Radix-4 digunakan sebagai alat analisis untuk melakukan Transformasi Fourier pada set data setiap ulangan dari masingmasing responden. Berikut adalah data hasil transformasi dalam domain frekuensi dengan menggunakan ketiga metode untuk setiap ulangan. 


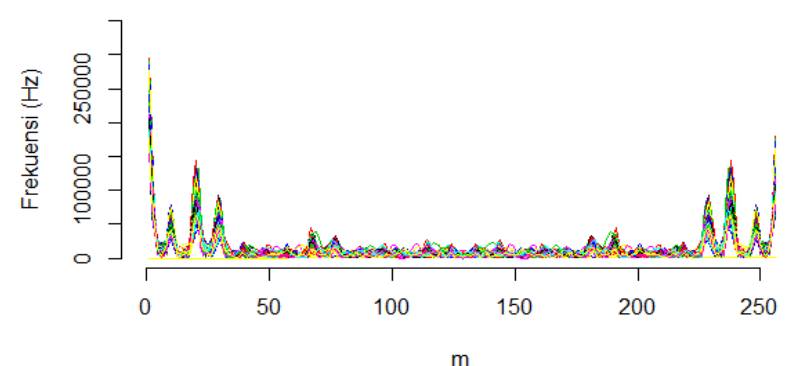

Gambar 5: Transformasi Fourier ulangan 1.

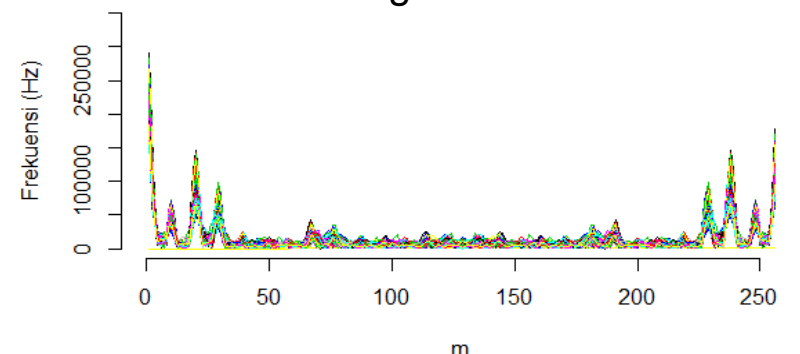

Gambar 7: Transformasi Fourier ulangan 3.

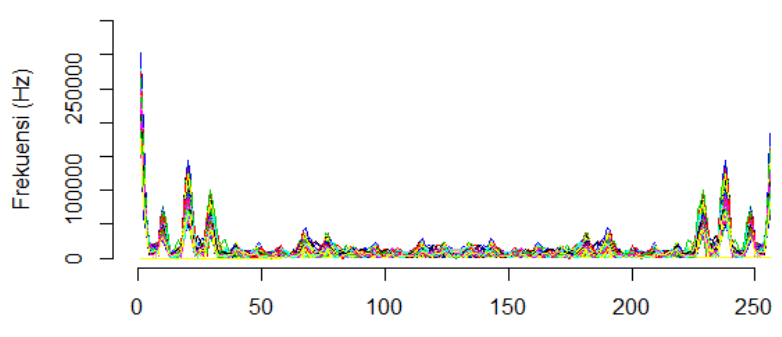

Gambar 6: Transformasi Fourier ulangan 2.

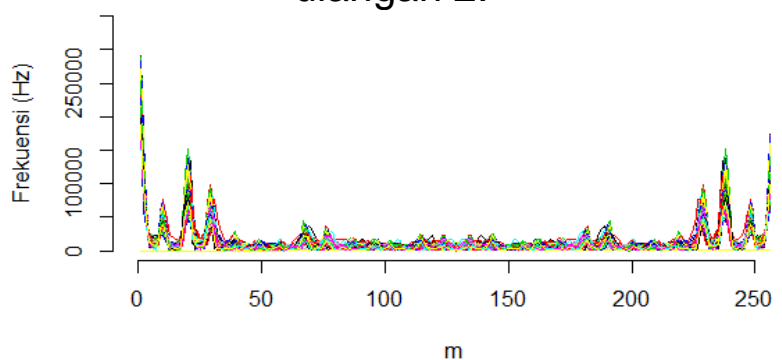

Gambar 8: Transformasi Fourier ulangan 4.

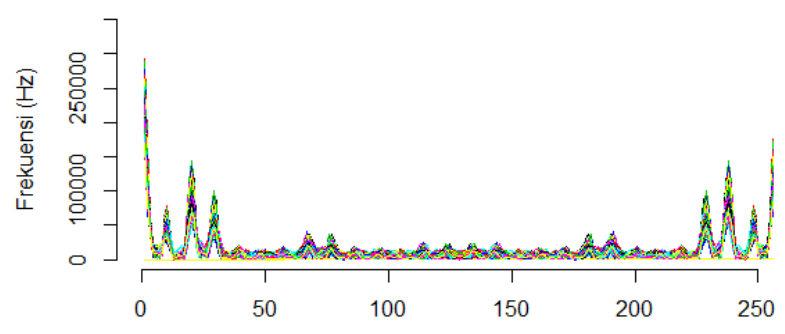

Gambar 9: Transformasi Fourier ulangan 5.

Berdasarkan Gambar 5, 6, 7, 8, dan 9 terlihat jelas bahwa pola grafik untuk masingmasing responden membentuk pola yang hampir sama pada setiap ulangan. Penggunaan program Discrete Fourier Transform, Fast Fourier Transform Radix-2, Fast Fourier Transform Radix-4 memiliki hasil transformasi yang sama. Hal ini dikarenakan metode FFT Radix-2 dan FFT Radix-4 merupakan pengembangan dari metode DFT. Gambar 10 merupakan contoh hasil transformasi pada Responden 03 (kadar gula darah $80 \mathrm{mg} / \mathrm{dll}$ ).

Penggunaan metode DFT, FFT Radix-2 dan FFT Radix-4 memberikan hasil yang identik (Gambar 10). Ketiga metode menghasilkan hasil transformasi yang sama sebagai akibat dari dasar algoritma yang digunakan sama yaitu metode Fourier. Oleh sebab itu, evaluasi pemilihan metode terbaik dapat dilakukan dengan membandingkan kecepatan pemerosesan dari masing-masing algoritma. Pengukuran kecepatan pemerosesan algoritma dapat diketahui dengan menggunakan bantuan software Matlab. Grafik kecepatan pemerosesan masing-masing algoritma digambarkan pada Gambar 11. 


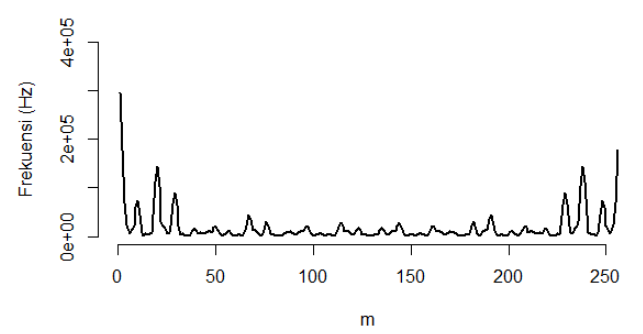

Output DFT

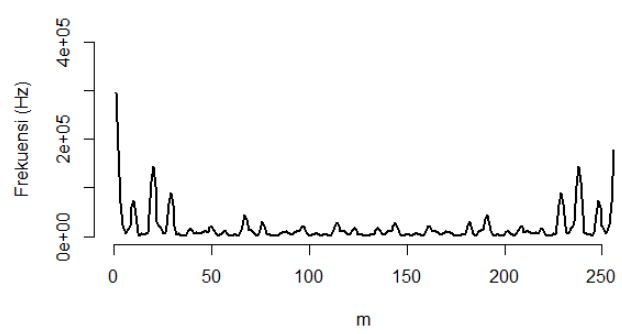

Output FFT Radix-2

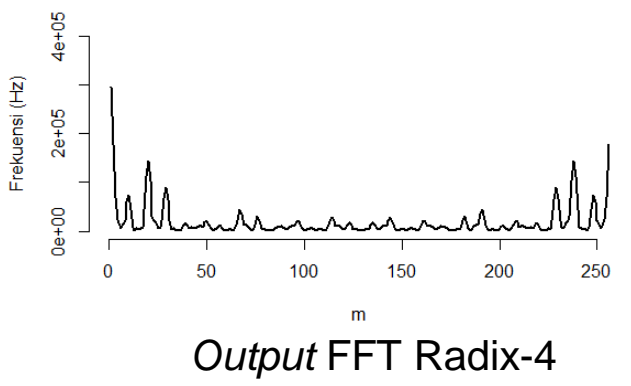

Gambar 10: Perbandingan hasil transformasi DFT, FFT Radix-2, dan FFT Radix-4.

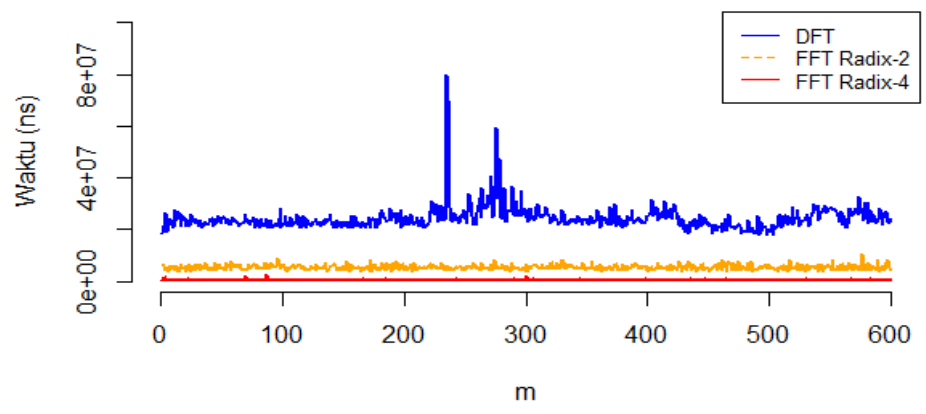

Gambar 11: Perbandingan kecepatan algoritma DFT, FFT-Radix-2, dan FFT Radix-4.

Berdasarkan grafik (Gambar 11) terlihat bahwa kecepatan pemerosesan dengan menggunakan metode FFT untuk melakukan transformasi ke domain frekuensi jauh lebih efektif jika dibandingkan dengan menggunakan metode DFT. Kecepatan ratarata pemerosesan dengan menggunakan metode DFT yaitu $2.43 \times 10^{7}$ nanosecond (ns) dengan kecepatan maksimum $1.77 \times 10^{7}$ ns. Rata-rata kecepatan metode FFT Radix-2 yaitu $5.33 \times 10^{6} \mathrm{~ns}$ dengan kecepatan maksimum $3.95 \times 10^{6} \mathrm{~ns}$. Kecepatan rata-rata metode FFT Radix-4 yaitu $2.67 \times 10^{5}$ ns. Adapun kecepatan maksimum pemerosesan dengan menggunakan metode FFT Radix-4 yaitu mencapai $1.92 \times 10^{5}$ ns.

\section{Kesimpulan}

Luaran purawarupa alat pendeteksian gula darah secara non-invasif berupa spektrum yang digambarkan dengan nilai residu intensitas dalam domain waktu sehingga perlu dilakukan transformasi ke domain frekuensi. Penggunaan metode Fast Fourier Transform sebagai bagian dari pra pemerosesan untuk melakukan transformasi ke domain frekuensi memiliki tingkat keefisieanan yang tinggi dibandingkan dengan metode Discrete Fourier Transfom. Peneltian ini menggunakan metode Discrete 
Fourier Transform, Fast Fourier Transform Radix-2 dan Fast Fourier Transform Radix4 untuk melakukan transformasi data ke domain frekuensi. Hasil Transformasi data dengan menggunakan metode FFT-Radix-4 lebih efektif dan efisien jika dibandingkan dengan metode lainnya. Kecepatan pemerosesan dengan metode FFT Radix-4 lebih cepat $5.06 \times 10^{6}$ ns dari FFT Radix-2 dan lebih cepat $2.40 \times 10^{7}$ ns dari metode DFT. Kecepatan pemerosesan menggunakan metode FFT sangat dipengaruhi oleh jumlah Radix yang digunakan, semakin tinggi radix yang digunakan maka kecepatan pemerosesan akan semakin meningkat, akan tetapi proses analisis data akan menjadi lebih kompleks.

\section{Daftar Pustaka}

Almeida-Trinidad, R., \& Garnica-Garza, H. (2007). A study on the application of Fourier series in IMRT treatment planning. Australasian Physics \& Engineering Sciences in Medicine, 30(4): 260-268.

Fain, J. A. (2009). Understanding diabetes mellitus and kidney disease. Nephrology Nursing Journal, 36(5): 465-470.

Jaladi, V., \& Swamy, K. P. (2015). Implementation and comparison of Radix-2, Radix4 and Radix-8 FFT algorithm. International Journal of Ethics in Engineering \& Management Education, 2(8): 40-44.

Kassahun, C. W., \& Mekonen, A. G. (2017). Knowledge, attitude, practices and their associated factors towards diabetes mellitus among non diabetes community members of Bale Zone administrative towns, South East Ethiopia. A cross-sectional study. PloS One, 12(2): e0170040.

Kim, T. (2003). Determination of Frequencies from Fringe Patterns Using Short-time Fourier Transforms and Wavelet Transforms (PhD Thesis). Chicago (US): Illinois Institute of Technology.

Lasijo, R. (2005). Perhitungan Transformasi Fourier Cepat 1-dimensi dengan Radiks Gabungan Em Pat dan Dua Serta Contoh Penggunaannya. Jurnal Sains Dan Teknologi Nuklir Indonesia (Indonesian Journal of Nuclear Science and Technology), 1(2): 99-119.

Li, Y. (1997). Mechanisms for platelet hyperactivity and abnormal calcium homeostasis in dia etes mellitus (Thesis). Winnipeg (CA): University of Manitoba.

Tedjo, A., Prafiantini, E., Suprapto, A. P., Ibrahim, A. S., Riyanto, S. A., \& Priyanto, D. (2014). A Simple Photometer as a Helping Device in Measuring Blood Glucose. Makara Journal of Health Research, 18(2): 77-80.

Wintarti, A., \& Suprapto, Y. K. (2011). Perbandingan Ketepatan dan Kecepatan pada Algoritma DFT dan FFT. Presented at the Semnastika-Unesa, Matematika Membangun Insan Kritis dan Kreatif, Surabaya (ID): Universitas Negeri Surabaya.

Zhang, J., \& Li, Z. (2013). An algorithm for computing the radix-2n fast fourier transform. Sensors and Transducers, 154: 260-265. 